Article

\title{
Here Come My 600-Pound Quintuplets: A Discussion of Reality Television as a Freak Discourse
}

\author{
Sandra Pitcher \\ Department of Media and Cultural Studies, University of KwaZulu-Natal - Pietermaritzburg, South Africa; \\ E-Mail: pitcher@ukzn.ac.za
}

Submitted: 31 January 2021 | Accepted: 22 April 2021 | Published: 13 September 2021

\begin{abstract}
History is littered with tales of the absurd, odd, and unusual. From Gorgons and mermaids to bearded ladies and elephant men, people have, for centuries, been fascinated by those who deviate from physical and mental social norms. Such fascinations seemed to peak during the 19th century when showmen, like PT Barnum, bought and exhibited those deemed too different and macabre for "normal" society. However, as science and medicine progressed, and the protection of human rights became more important, freak shows and travelling sideshows dwindled (Nicholas \& Chambers, 2016). Society's fascination with the unusual though, did not. Despite increased political correctness and calls to end "fat shaming," bullying and the like, reality television appears to encourage "a dehumanising process that actually lessens our regard for other people" (Sardar, 2000). While some writers have considered how reality television exploits stereotypes and links social norms to hegemonic whiteness (Cooke-Jackson \& Hansen, 2008; Rennels, 2015), few have commented on the similarities between such programming and the stylings of the 19th century freak show. Utilising Thomson's (1996) concept of freak discourse, and Bogdan's (1996) assessment of freak narrative, this article examines how reality television programming as a genre, despite its varied plots, uses a narrative formula that can be likened to 19th century freak shows to enhance its storylines and "produce a human spectacle" (Thomson, 1996, p. 7).
\end{abstract}

\section{Keywords}

freak discourse; popular culture; reality television; television studies

\section{Issue}

This article is part of the issue "From Sony's Walkman to RuPaul's Drag Race: A Landscape of Contemporary Popular Culture" edited by Tonny Krijnen (Erasmus University Rotterdam, The Netherlands), Frederik Dhaenens (Ghent University, Belgium) and Niall Brennan (Fairfield University, USA).

(C) 2021 by the author; licensee Cogitatio (Lisbon, Portugal). This article is licensed under a Creative Commons Attribution 4.0 International License (CC BY).

\section{Introduction}

In its tagline, the cult classic Freaks (Browning, 1932) asked, "[can] a full grown woman truly love a midget?" Critics were horrified, the public fascinated. MGM Studios withdrew the film (despite decent box office earnings) after a number of complainants cited that the film concentrated too heavily on "the most unsavoury aspects of the freak show" (Hawkins, 1996, p. 265). One of the reasons for such outrage lent on advances in medicine and science during the first half of the twentieth century. As these professions developed, so too did society's sensibilities toward those who appeared in sideshows and circuses. "People with disabilities started to be viewed as... having various genetic and endocrine disorders" (Bogdan, 1996, p. 33) to be treated, rather than deformities to be ogled. And those who were termed "exotic" only a few decades prior, were no longer that unusual as more people began to travel, and diasporic communities flourished in big cities. Consequently, the few side shows that remain today, tend to be seen as exploitive and "seedy vestiges" of a time gone by (Bogdan, 1996, p. 23). Yet despite such changes to society, and the rights movements they encouraged, freak discourse remains intact, and embedded in more contemporary disciplines such as genetics, zoology, embryology, taxidermy, and celebrity culture (Thomson, 1996). 
As Thomson (1996, pp. 1-2) points out, humans have a "seemingly insatiable desire to gawk" and a "profound disquiet [stirs] in the human soul by bodies that stray from what is typical and predictable." While academic work in literature (including film studies) are littered with analysis of the "other" and grotesque, few appear to have plotted the role that freak discourse plays in creating narrative. Other contemporary work has hinted at how television in the form of talk shows (see Dennett, 1996) and medical documentaries (see Clark \& Myser, 1996) contain aspects of freak discourse, but none have gone so far as to directly link their studies to how these discourses have revitalised the conventional 19th century freak show into 21st century reality television. I argue in this article that reality television mirrors the same discourses used by freak shows in the late 19th century to attract audiences and drive their narratives, falling back on many of the techniques, described by historians and academics, which were used by sideshows and circuses. Like freak shows, reality television is "about spectacle: it is a place where human deviance is enhanced, dressed, coiffed, and propped up for the entertainment of paying audiences" (Bogdan, 1996, p. 325).

Therefore, this article opens with a short history about reality television and the complexity in its definition. From there, a comparison is made between reality television and freak shows of the 19th century. The discussion then moves on to apply Thomson's (1996) work to selected examples, highlighting that it is not merely those programmes which deal with the so-called grotesque, but that most shows hinged on faux-reality follow the formula of freak discourse. Finally, the article ends with a discussion of themes contained in various examples, highlighting how these mirror Bogdan's (1987, $1988,1996)$ assessment of conventional freak shows, concluding that Western society is no more "civilised" than it has ever been. Notably, this article deals broadly with the genre of reality television in light of freak discourse. Consequently, the research achieves a methodological framework which can be utilised in future case study analyses.

\section{Reality TV or Freak Show: Is There a Difference?}

Reality television is a somewhat complicated genre, without much consensus as to how to classify it. Part of the problem is that it is a postmodern hybrid that borrows elements from many other genres like documentary, talk shows, game shows, and even home movies. Some trace the genre back to the 1960s and the introduction of Candid Camera (Clissold, 2004), but the genre only really began to gain traction in the early 1990s (Holmes \& Jermyn, 2004). Originally, the genre was confined to "factual programs containing 'on-scene' footage" (Hill, 2005, p. 468), such as the Rodney King assault in 1991, but this became too restrictive as newer "fly-on-the-wall" documentaries proliferated 1990s primetime slots (Hill, 2005). Programmes like Rescue 911, Cops, and America's
Most Wanted, re-presented real events in dramatised formats, inviting audiences to experience life as an emergency worker, while other extreme talk shows, like Jerry Springer, exploited salacious scandals that were usually kept out of the public eye. The commonality with these programmes, as outlined by Hill $(2005$, p. 451$)$, was that they were "a combination of observational documentary and character-driven drama" that were obviously scripted and edited.

However, when shows like Big Brother and Survivor catapulted into viewers' homes in the early 2000s, many writers thought that the genre had shifted into one which offered unmediated insight into the private lives of ordinary people (Biressi \& Nunn, 2005; Oulette \& Murray, 2004). Even medical docu-soaps, which focussed on abnormal bodies within the privacy of a surgery, were no longer seen as "real" because they were often dramatised, and only tended to allow viewers in via invitation through the perspective of "the benevolent work of heroic physicians" (Clark \& Myser, 1996, p. 338), rather than alongside the "lived" experience of a patient. Nevertheless, the "realness" of reality television was quickly brought into question. Despite shows like Big Brother, which appeared unedited and unmediated, it became widely understood that these types of programmes were carefully constructed and manipulated by producers. In essence, the only useful description that could be used when trying to classify generic cues in reality television are the ways in which programmes "invite viewers to voyeuristically observe" (Biressi \& Nunn, 2005, p. 116) the ways of living, which are typically off-limits in other genres. O'Donnell (2017, p. 125) concurs, highlighting that reality television, and the myriad of sub-genres it has spawned, encourages "audience voyeurism" which provides audiences "a sense of contact with what is real rather than what is fiction." Additionally, researchers continue to raise two common themes in relation to reality television which aid in its definition.

Firstly, reality programmes provide viewers an opportunity to deal with social identity (as does most television). However, Biressi and Nunn (2005) argue that reality television, unlike conventional television, provides "real" stories about "real" people with whom audiences are able to relate, and thus provide a sense of social legitimisation. In other words, reality programming allows audiences to say to themselves, "I'm not alone, others are dealing with the same traumas as me." Biressi and Nunn (2005) lament that audiences appear to be using what they see on reality television as a way to authenticate their existence. Briggs (2009, p. 48) agrees and describes television as a "modern confessional" that provides viewers significant interaction around intimate topics that would otherwise be kept hidden. In doing so, audiences are presented with various social options in terms of how to behave and react when "faced with challenging situations" (Briggs, 2009, p. 51).

However, this idea is not new. Franzino (2015, p. 189) pointed out that that during the late 19th century "what 
audience members saw on the sideshow stage shaped their ideas about identity, normality, and communal and national belonging." Thomson (1996, p. 11) argued a similar point, stating that "freak shows became ritual sites where the uncertain polity could anxiously contemplate the new parameters of embodiment that cultural transformations had wrought." And while Thomson (1996) was referring to the uncertainty that industrialisation and mechanised factories posed for the "normal" body in the early 20th century, there are obvious similarities today as artificial intelligence and robotics become more advanced. Therefore, reality programmes, like freak shows, are "filled by voices proclaiming and celebrating their own 'freakishness'" (Biressi \& Nunn, 2005, p. 107) to help articulate viewers' personal insecurities and anxieties in ways that would otherwise not be possible in the normalcy of day-to-day living. Consequently, Hill (2007, p. 108) concludes that viewers use reality television as a way to "explore the troubling or negative aspects of their self-experience."

Secondly, reality television reinforces hegemonic norms by using those who deviate from these (whether physically, or psychologically) as examples of how not to behave. Jones (2018, p. 28) argues that "reality television shows seek out the worst of humanity [in order] to reflect it back at [audiences]" as it flirts with moral and immoral behaviour, creating a dichotomy between us (moral) and them (immoral). When viewers sense those boundary lines have been pushed too far, they recognise the dangers of deviating too far outside the norm of proper social interaction and draw back with indignation. In the words of Hill (2007, p. 108), such interactions "appear like a 'mad dream" " which viewers are only able to escape if they return to the sanity of hegemonic normalcy. Consequently, reality television deals with such anxieties by appealing to a "mythic past where gender norms [are] absolute [and] the nuclear family," as well as the average white middle-class, are considered the "ultimate normalising rite" (Stephens, 2004, p. 193). The spectacle of placing alternatives to such norms is used as a display to "warn others of the dangers of defying society's modus operandi" (Rennels, 2015, p. 274).

Again, one finds similarities between such descriptions and those which described freak shows. Thomson's (1996, p. 4) work highlights how the unusual body, relationship or mentality were considered as an "especially vicious normative violation, demanding genetic reconstruction, surgical normalisation, therapeutic elimination, or relegation to pathological specimen." The extreme freakishness of performers in side-shows and circuses allowed the common petite bourgeois audience to be "rendered comfortably common and safely standard by exchange" (Thomson, 1996, p. 5). In other words, audiences knew that by maintaining normalcy and nondeviant behaviour they were morally sound and aligned with successful modern living, unlike the freaks of the sideshow. However, the true parallels between freak shows and reality television can be drawn from an ana- lysis of freak discourse itself, as many reality shows (even those which appear to encourage positivity) use the same structures to advertise and drive freak show performance.

\section{Freak Discourse}

Thomson (1996) argued that the conventional 19th century sideshow was underpinned by four interwoven narrative forms which helped to produce freak discourse. The primary stage comprised of the oral spiel, or "lecture," which was touted outside the main side show tent. The showman, most commonly referred to as a "doctor," "lecturer," or "professor," would deliver a speech, often with a relatively tame-looking freak beside him, to help whet the intrigue of passers-by and potential customers. He would advertise amazing dwarves, intriguing giantesses, sword swallowing marvels from the East, human torsos without arms or legs who could light and smoke cigarettes, or even animal-people who were half man and half beast. Today, such proclamations may seem offensive, yet simultaneously somewhat familiar; especially when flipping through reality television channels. Viewers are offered a choice of programming which offer insight into the escapades of "the largest known family of little people in the world" (7 Little Johnstons), "America's fattest teenager" (The 685/b Teenager), or a man with an implied harem of 25 women (The Bachelor).

Additionally, as freak shows peddled "doctors" and "professors" to legitimate the scientific and educational merit of such human oddities, so too do reality television shows. One can use literal examples like Dr Miami, Dr Pimple Popper, and Dr Christian, which use real doctors to help participants overcome some type of medical or psychological malady. But, it must be remembered, that like credible doctors who were used by freak shows to lend credence to the scientific and educational merit of certain exhibits, those who feature on medical reality programmes, are driven by "a for profit activity, and within the climate of the amusement world" (Bogdan, 1996, p. 25). However, the role performed by freak show orators is probably best represented by reality television narrators and hosts who direct audiences to take heed of participants strange conditions and outrageous behaviour. In South Africa's Date My Family, for example, the narrator, never seen by the audience, introduces the potential bachelor or bachelorette, and provides information and details about their wants, desires, and often salacious expectations. Such narration is similar in other shows, like Come Dine With Me or Dinner Date, in which the narrator often responds to bizarre or strange behaviour displayed by contestants with sarcastic quips (not heard by the participant). Consequently, the narrator guides audiences through these types of shows highlighting that specific types of behaviour should be met with audience derision, and essentially pinpoints what type of behaviour is deemed socially acceptable or not. Date My Family is an excellent example of such direction. Despite sharing the same general format as 
other dating reality shows, its primary audience are middle-class Black South Africans. One might assume that this would spark a narrative which deviated from the "whiteness" of other international shows. However, what emerges is not only a narrator who quips about contestants' strange wants and desires in a partner, but also makes light of their cultural belief systems. Often, male contestants when meeting the family of a potential female partner, tend to describe their perfect relationship as one which adheres to culturally traditional gender roles: Women are expected to be the homemaker, respectful to the wants of their man, and provide sex when her partner demands. Nevertheless, what one often hears thereafter from the narrator is that many of these cultural expectations are archaic and not desirable for those who wish to be part of modern-day South Africa. Overall, the narrator seems to advocate for the same social norms as found in other contemporary dating shows imported from the West.

The second narrative form, as outlined by Thomson (1996), revolves around texts which were publishedin the form of pamphlets, advertisements, and newspapers - that provided detailed biographies about each freak. Importantly, as explained by Bogdan (1996, p. 25), advertisers of freak shows were careful to construct "a public identity for the person that was being exhibited... designed to market the exhibit [and] produce a more appealing freak." Again, one can see the same technique used in reality programming as advertisers and producers provide biographical backgrounds for participants, promotional videos, and appearances on various talk shows. As can be noted in the extract below, taken from MSN Entertainment about the reality programme Outdaughtered: Life with the Quints, audiences are primed to consider participants as abnormal:

In April 2015, [a] Texas couple became parents to the first-ever all-female quintuplets born in the U.S. The new additions-Ava, Olivia, Hazel, Riley and Parker-join 4-year-old Blayke, turning a family of three into a bustling household of eight overnight. "Outdaughtered" profiles the Busbys' journey, focusing on the babies' delivery and the massive adjustment period that follows. Lending muchneeded help are Danielle's older twin sisters, Ashley and Crystal, and her zany mom, Michelle. (MSN Entertainment, 2016)

Based on this extract, the couple are seen as odd as they are forced to make adjustments to accommodate their unconventional family. Additionally, by including their extended family, who are considered "zany," audiences are asked to judge the non-conventional family dynamic as strange, bordering on crazy. Evidently, the show acts as a cautionary tale, as many freak show acts did, of what to expect if one deviates too far outside Western familial norms of the traditional nuclear family. This is only one of many programmes which deals with alternative family living. In programmes like Welcome to Plathville and 19 Kids and Counting, audiences are invited to visit the websites set up by each family to see more about their ultra-conservative Christian lifestyles. Together with advertisements and gossip magazine space about family scandals (such as molestation charges; see Swift, 2015), audiences are left questioning if this type of lifestyle is not "cult-like," and one that should be avoided-just as would have happened when reading about the lifestyle of African "savages" found in 19th century sideshow pamphlets.

Thomson's (1996, p. 7) third aspect of freak discourse concentrates on "staging which include[s] costuming, choreography, [and] performance." Such description draws obvious parallels to the staging of all media, but is especially important in relation to reality television. As already discussed, the reality in reality television is a trope as programmes are constructed, scripted and edited. Even Big Brother, which was meant to be an unmediated broadcast that "shattered the fourth wall and invited viewers behind the scenes" (Andrejevich, 2004 , p. 120), was manipulated by producers who chose participants based on psychometric tests, and often influenced them, and thus their interactions, during sessions in the diary room (Knox, 2016). This mirrors many of the techniques used by freak show exhibitions whereby showmen would create fabricated personal histories for their performers, carefully constructed stories about how they ended up as part of the freak circuit, and what their current personal circumstances were like (Bogdan, 1996). Apart from the Wild Men of Borneo (discussed later), one of the most carefully constructed characters was General Tom Thumb. Born Charles Sherwood Sutton in 1838, General Tom Thumb became one of PT Barnum's most well-known oddities. Touted as an eleven-year old, Sutton was only four when he began working for Barnum. He was renamed Tom Thumb, after the English fairytale character, and promoted to General to help bolster his status as a remarkable adult oddity; all of which was reinforced by his characteristic army uniform and performances satirising Napoleon Bonaparte (Bogdan, 1996). He was even married off by Barnum to another small person to maintain his celebrity. More recently, Rennels (2015) has highlighted that similar audience manipulation occurs in reality television and uses the programme Here Comes Honey Boo Boo as a case study for her argument.

In this show, audiences are introduced to child pageant star Alana (Honey Boo Boo) Thompson, and her "redneck" American family. The programme, which centres on the family's life, is intentionally edited to show off the family's worst behaviours and teach Americans "what not to do and who not to be in the United States" (Rennels, 2015, p. 275). The family were displayed as uneducated, uncouth (often farting on-camera), and immensely unhealthy. To enforce the concept that the Thompsons were not the family any respectable white American would want to emulate, directors even took to 
editing in shots of a train that was allegedly meant to pass by the family's home, highlighting that they were indeed from the "wrong side of the tracks." Not once during the series was the family shown as having bettered their social position or improved their lifestyles as a result of their earnings from the show (despite earning an estimated $\$ 50,000$ per episode). Therefore, just like the narratives around the characters found in freak shows, Here Comes Honey Boo Boo, like all reality television, is knitted together to produce a carefully crafted narrative which appears to naturalise performance, and manipulate audiences into believing that they mimic the "true" reality of performers.

The final aspect of freak discourse which Thomson (1996, p. 7) discusses deals with how sideshows were tied together by images which pitted "staged freakishness" against the "proper" "Victorian parlor and family album." Obviously we are not judged against the social decorum of Victorian sensibilities today, but comparison between "proper" and "improper" behaviour on reality television is a basic tenet of the genre. Between reality programming that draws attention to unusual maladies or relationships, and poor social status, one also finds another type of show: one which tends to highlight lifestyles on the opposite end of the spectrum. In programmes like Say Yes to the Dress and House Hunters International, viewers are given the opportunity to experience the benefits that one can achieve when adhering to Western hegemonic social norms. In retrospect, shows like Here Comes Honey Boo Boo and Swamp People, demonstrate that to be white and relatively unattractive, of low intelligence, and poor is the equivalent of being an undesirable social freak. Other programmes which highlight the attractiveness of white middle-class living, and above average education, provide participants opportunities for fairy-tale happy endings. However, those who deviate too far into the realm of the extremely wealthy, or from hegemonic middle-class whiteness, are also represented as undesirable. For example, in programming like Jersey Shore, The Real Housewives Series, and Bling Empire, viewers are asked to judge the lifestyles of participants who are often shown as crude, overly sexualised, spoiled, and thus abhorrent to conventional white Western, middle-class social etiquette. In other words, these shows tend to highlight the classlessness of overt wealth, especially if it is in the possession of non-white actors and spent in ways that are considered flamboyant. In doing so, these narratives help maintain the idea that it is better to aspire to be part of the typical white uppermiddle class, thus re-affirming the privilege of this group, than deviate too far on either side of the spectrum. Such conclusions are further reinforced when exploring the work of Bogdan (1996).

\section{Freakish Constructions on Reality Television}

Like reality television, the aim of conventional freak shows was to turn a profit. The ways in which acts were constructed and marketed helped increase earnings. The more outrageous the spectacle attached to a specific act, the greater the amount circuses and sideshows could charge. As with reality television, there were a variety of freak shows that were available to audiences. These tended to be differentiated between those freaks who were "born," "made," or provided some form of "novel" act. In other words, there were performers who were born with some type of malady or deformity such as Prince Randian, more commonly known as the Human Torso, who was born without limbs; other performers who made themselves into freaks, such as Captain George Costentenus, who was covered in tattoos; and novelty acts, in which exhibitions performed strange and exotic routines, such as sword swallowing or eating glass.

One doesn't have to search too hard to find the same "types" of performers on modern reality television. Those who are born different often appear in programmes like 7 Little Johnsons (a show about a family of seven small people), Outdaughtered (a programme which documents the day-to-day life of a husband and wife with six daughters) and, to mirror the example above, TLC's Born Without Limbs; a show which follows the day-to-day life and challenges of Nick Vujicic, a man who was born without arms and legs. Other shows, like Black Ink Crew, Tattoo Girls, and Botched follow the lives of those who have made themselves into something different, whether it be through tattooing or plastic surgery. Interestingly, Botched deals with individuals who have undergone plastic surgery and are either looking to correct botched surgeries, or undo a poor surgery decision (such as over-enlarged breast implants). Consequently, the overall message of the show teeters back toward the idea that one should adhere to typical social norms regarding appearance, or face the horrible prospect of corrective surgery and/or ridicule from society. Not only does Botched detail the surgery needed to fix a patient, but also the agony of recovery, thus providing even more traumatic material to further discourage audiences from unnecessary cosmetic deviations. Additionally, today's novelty acts, while not usually as extreme or dangerous as sword swallowing, can be linked to programming like Fear Factor, American Idol, Britain's Got Talent, and Survivor. However, even in these shows, producers tend to focus attention on contestants who are different in some way, such as Susan Boyle, a frumpy Scottish woman, who shocked both audience and judges on Britain's Got Talent with her rendition of I Dreamed a Dream. Boyle did not "fit" with the conventional image of a pop singer, and was laughed at by both studio audience and judges when she first took to the stage. However, she stunned everyone into silence when she began to sing and was proffered an apology from judge Simon Cowell at the end of her performance for judging her on her appearance.

Based on the above criteria, Bogdan (1996) argued further that freak show performers generally fell into one of two modes of performance, based on how a sideshow 
was constructed: the exotic mode and/or the aggrandised mode. I argue that modern reality television also follows the same formula.

In relation to the exotic mode, Bogdan (1996, p. 27) considered sideshow acts which "appealed to people's interest in the culturally strange, the primitive, the bestial, [and] the exotic." In other words, any act which suggested that performers were from an exotic land, or displayed characteristics similar to animals fitted into this category of freak. Some of the most famous acts to which he refers were the Wild Men of Borneo, the Elephant Man, and Prince Randian. However, most of these acts relied on audiences' limited worldliness, and showmen's aptitude and orchestration of manipulation. The Wild Men of Borneo, for example, were touted as two savages who had been captured after an intense physical struggle with sailors visiting the distant island of Borneo in the Pacific. In reality, they were two mentally disabled (but very strong) brothers from New Jersey who were acquired by PT Barnum (Bogdan, 1988). And despite what one might assume, these performers, like many other headlining acts in Barnum's shows, died incredibly wealthy. Others were not so lucky. Annie Jones, more commonly known in Barnum's circus as the Bearded Lady or Monkey Girl, was essentially sold into his employ by her parents as a baby, and Joice Heth, a blind and almost paralysed slave, advertised as the oldest woman on Earth at 161, was rented from her owners by Barnum for $\$ 1,000$ a year. Consequently, many exotic acts were underpinned by racist ideologies and determined by ethnology in which exoticism was likened to those deemed "primitive" in light of Western society's assumed civility (Cassuto, 1996; Rothfels, 1996).

Freak shows generally sourced exotic acts (or at least pretended to in some cases) from outside the Western world. Audiences were told that exhibits "came from a mysterious part of the world-darkest Africa, the wilds of Borneo, a Turkish harem, [or] an ancient Aztec kingdom" (Bogdan, 1996, p. 28). Those on display were scripted to behave in a stereotyped and primitive manner (like grunting and knuckle-walking) to validate orators' "lectures" about their origins and narratives as audiences made their way through the exhibit. Therefore, the exotic mode tended to make people freaks because of the "racist presentation of them and their culture by promoters" (Bogdan, 1996, p. 29), and their opposition to how one was meant to behave in civilised modern Western society. While reality television producers may not be quite as obviously racist in their construction of the exotic today, there is still plenty of evidence to suggest that such categorisation is used, whether consciously or not. However, what is interesting to note, is that when one begins to look for examples, especially from programmes that are syndicated out of the US for global broadcast, the exaggerated "other" tends to focus on either "uncivilised" rednecks, or immigrants in the US. Two examples to be noted are Swamp People and Cake Boss respectively.
In Swamp People, a History Channel production, participants are represented as partaking in a way of life that is foreign, and somewhat strange in relation to standard expectations of modern American living. Despite filming around different swamps throughout the southern US, the show's official webpage cites that the show provides insight into the "proud descendants of French Canadian refugees who settled in the swamp region of Louisiana in the 18th century" and now hunt alligators in the Louisiana delta, just as their ancestors did, to help preserve their traditions (History Channel, 2021). When the programme first began, it often relied on subtitles, due to actors' thick regional accents, and audiences were propelled into the backwaters of the American continent with men who appeared bestial. Not only did they hunt and wrestle alligators to sell for meat and skin, they were large, bearded, and seemingly unwashed. Overall, they appeared as the epitome of the Ape Men from HG Wells' The Lost World. Such representations point directly back to Bogdan's (1996) work on exotic freak shows, whereby some individuals who spoke a primitive language and/or partook in eating animals that would repel typical Western sensibilities, helped display and reinforce their "savagery." It could also be argued that in 21st century society, and the continual rise of animal rights, that the sale of alligator skin, as well as its meat, is akin to the same "barbarous" behaviour, and in direct contrast to the morals and values of contemporary Western society.

However, it is not only programmes which highlight extreme social behaviour or difference which follow the path of exotic freak discourse. Programmes like Cake Boss use scripting and stereotypes to embolden their narratives to reinforce exoticness. Documenting the day-to-day life of a successful New Jersey baker, and first generation Italian-American, Buddy Valastro, one could assume that Cake Boss is an example of aggrandised freakishness (to be discussed below). Instead, it can be examined as part of the exotic thanks to producers' use of stereotypes related to Italian-American immigrants. Cake Boss often focusses on Buddy's Italian heritage and large conventional Catholic family, introducing each show with Valastro stating: "This is the crew, mia famiglia. We're going to take this bakery to the top. They call me Buddy, I'm the boss" (Feeley et al., 2009present). By using phrases like "the crew," "mia famiglia" (my family, in Italian), and "the boss," one is reminded of the same type of discourse used in American gangster movies, and how Italian-American families were often linked in the media to organised crime and the Mafia. Throughout the series, Buddy is portrayed as a "Don"-like figure who oversees his entire bakery operation and family, much like a crime boss in old gangster films. Audiences also see him and his family partake in important Catholic rituals, such as christenings and weddings, which help focus audience attention to their familial bonds. Such displays help to further links between the Cake Boss and stereotypes from movies such as 
The Godfather, as many important business decisions are made during these meetings. Additionally, Cake Boss is a rags-to-riches story of a first-generation immigrant who is living the American dream (another common theme in the gangster genre), thanks to his cake empire. Interestingly, the show often shows Buddy and his family flaunting their riches, either on expensive holidays, or on seemingly frivolous household luxuries, such as a home bowling alley. Consequently, the show couches itself in stereotypes that "other" Italian-Americans as immigrantexotics who do not quite "fit" into the norms of conventional middle-class America, and should be looked at with caution, even while the programme reinforces the success that one can enjoy by partaking legally in the United States' capitalist economy.

Additionally, remnants of racist stereotyping, as first witnessed in freak shows, is still evident in modern reality television. Notably, the representation of non-white participants in US reality shows are either positioned as wealthy socialites in programmes like the Hip-Hop Wives series, or Basketball Wives, or as criminals in shows like Cops or Border Security: America's Front Line. There appears to be no middle-ground in terms of how nonwhite Americans are portrayed on reality television, and thus implies that they do not (or cannot) "fit" into the ideals of white American life. Such othering is portrayed in other countries, but manifest in different ways. In South Africa, for example, most reality shows feature black participants, and the concept of the exotic manifests in relation to tribal differences. One such example was witnessed in The Real Housewives of Durban in 2021 when Ayanda Ncwane, a Zulu participant, inferred that another participant, Nonkanyiso Conco, who is Tswana, was not human because she is not Zulu. Interestingly, despite the furore this altercation caused on social media, the incident seemed to be swept under the carpet by producers (possibly pointing to the privilege Zulus hold as the dominant population group in the country). However, despite portraying smaller tribes as exotic, the overall discourse of these shows in South Africa mimic the same ideology of American reality television-success is measured by how well one meets the ideals of a white Western middle-class.

In addition to the exotic mode of freak discourse, Bogdan (1996) argues, much like Thomson (1996), that freak shows also cast actors in an aggrandised manner, rather than exotic and othered. As was mentioned previously, conventional freak shows often paraded less offensive freaks in a manner which elevated them in way to lay "claim to the superiority of the freak" (Bogdan, 1996, p. 29) and draw audiences in. This article has already mentioned the unexpected talents of Susan Boyle and Nick Vujicic, thus hinting that basic aggrandisement occurs when a person shows a talent that "normal" society would believe to be unexpected from an exhibit. However, the most common type of aggrandisement is merely standard show business and was linked, when referring to sideshows, to those individuals who "were carefully groomed and trained for exhibit" (Bogdan, 1996, p. 30). In modern reality programming, this can be linked to almost any reality show in which participants are coached (The Voice, America's Got Talent, Pop Idol), mentored (Project Runway, America's Next Top Model, Next Great Baker), or just carefully narrated in their dayto-day lifestyles (Keeping Up With The Kardashians, Girls of the Playboy Mansion, Real Housewives).

In fact, much of today's celebratory culture is rooted in the aggrandisement of reality stars. Talent competitions like American Idol or Chopped, are obvious sources from which producers are able to discover singers, chefs, actors, models, and designers. However, reality television is also responsible for celebrity production or, as termed by Thompson et al. (2015), the creation of "celetoids," such as The Kardashians. Such celebrities are created thanks to "close collaboration between the cast and the production team" (Thompson et al., 2015, p. 482) and the seemingly unfettered access audiences are given into their "real" everyday lives. Celetoids do not have any talent per say, except being wealthy (usually). However, the spectacle of their opulent lifestyle, and by allowing audiences to voyeuristically observe their day-to-day lives, the Kardashians, like most celetoids, have been carefully crafted for audience consumption, thus making them household names. Thanks to the success of the show, each member of the Kardashian family has been able to profit off their celebrity, and launch different products such as perfumes, clothing lines, and cosmetics. Most have also landed lucrative endorsement deals with major brands such as Pepsi, SugarBear Hair Vitamins, and Proactiv. And most of this is a direct result of exaggerating and coiffing their wealthy lifestyle, rather than as a result of any remarkable or unique talent.

However, it is not unusual for acts to cross the boundary between the exotic and othered to an aggrandised act that is trained and exhibited, and back again. Bogdan (1996, p. 32) reflects on two conjoined twins, Millie and Christine, who, rather than just a deformed oddity "became celebrated Victorian singing nightingales" in PT Barnum's circus after Barnum discovered their talent for singing. Again, we can see many examples of the same type of thing among the myriad of reality programming. In the previously mentioned show Here Comes Honey Boo Boo, which was cancelled after four seasons, the fame of the family allowed them to create the spinoff series Mama June: From Not to Hot. In this new show the audience followed Alana's mother, who was ridiculed for her weight and bad manners during the original show, and watched her train, both physically and behaviourally, into a more attractive and "acceptable" American woman. Over the course of the first season, viewers watched Mama June lose over $120 \mathrm{kgs}$. However, the next three seasons returned to the basic tenets of exotic freakism as the family and Mama June fall back into their stereotyped redneck ways of life (although Mama June does keep her weight down). During this period, Mama June and her boyfriend were arrested for 
drug possession which then allowed for another spinoff production: Mama June: Family Crisis. This spin-off saw the family attempting to deal with Mama June's drug addiction and arrest, as well as how the family coped during this period. The spin-off ended after Mama June completed a drug rehabilitation programme in 2020, and has now led to a further series, Mama June: Road to Redemption, which is currently premiering on We TV. Consequently, the family constantly flitters between "other" and aggrandised as producers try to keep their franchise profitable; much like PT Barnum did with many of his exhibits as their acts waned and required revitalisation.

\section{Conclusions}

Ironically, many authors' work on sideshows and freak discourse conclude that the "concept of 'freak' no longer sustains careers" (Bogdan, 1996, p. 35). However, what has emerged from the discussion above is evidence that this is not the case. The term "freak" may have fallen out of fashion, but freak discourse is alive and thriving as revealed in the many examples above. Bogdan's (1996) modes of freak performance, coupled with Thomson's (1996) narrative forms of freak discourse, highlight that reality producers create characters based on stereotypes, difference, and aggrandisement in ways similar to those of 19th century sideshow owners. Reality television offers the public a voyeuristic glimpse behind the metaphorical curtain into a world that often rocks their sensibilities, just as exhibits did in circuses like PT Barnum's back in the 1800 s. Reality programming provides room to engage with moral and immoral aspects of modern society; right from wrong. In fact, reality television is so rife with freak discourse that, as this article has argued, it can be applied to almost any programme which falls into the reality category. However, while it was acknowledged that there are some overlaps which occur between reality television and other genres (like documentary), freak discourse does not manifest as easily within these other genres. Possibly, this is the result of one key difference: documentaries, conventional talk shows, news, and other non-fictional programmes are created under the tenet of informing, educating, and entertaining audiences (Bignell, 2004). Reality television is concerned with entertainment and profit first; social education is a fortunate supporting act. Documentaries also "tend to focus on correction" (Clark \& Myser, 1996), whereas reality television, which can groom and train individuals, does not aim for permanent correction, as evidenced in the case of Mama June. The aim is to keep shows on the air for as long as possible, and thus keep performers performing for as long as possible, or until they are no longer profitable. Just like freaks of the past, some reality stars leave wealthy, but many are spit out at the end just as destitute as they were when they started. Reality stars are no different from the freaks of the $1840 \mathrm{~s}$, and society is no less polarised. Therefore, despite much social progress, one can also conclude that thanks to certain representations within reality television, the entertainment industry still has a way to go before it can be considered a "civilized" medium.

\section{Acknowledgments}

I would like to thank my colleague, Prof Nicola Jones for her valuable feedback on earlier drafts of this article.

\section{Conflict of Interests}

The author declares no conflict of interests.

\section{References}

Andrejevich, M. (2004). Reality TV-The work of being watched. Rowman \& Littlefield.

Bignell, J. (2004). An introduction to television studies (3rd ed.). Routledge.

Biressi, A., \& Nunn, H. (2005). Reality TV-Realism and revelation. University of Michigan Press.

Bogdan, R. (1987). Exhibition of mentally retarded people for amusement and profit, 1850-1940. American Journal of Mental Deficiency, 91(2), 120-126.

Bogdan, R. (1988). Freak show. University of Chicago Press.

Bogdan, R. (1996). The social construction of freaks. In R. G. Thomson (Ed.), Freakery: Cultural spectacles of the extraordinary body (pp. 23-27). New York University Press.

Briggs, M. (2009). Television, audiences and everyday life. Open University Press.

Browning, T. (Producer \& Director). (1932). Freaks [Motion Picture]. MGM Studios.

Cassuto, L. (1996). "What an object he would have made of me!": Tattooing and the racial freak in Melville's Typee. In R. G. Thomson (Ed.), Freakery: Cultural spectacles of the extraordinary body (pp. 234-247). New York University Press.

Clark, D. L., \& Myser, C. (1996). Being humaned: Medical documentaries and the hyperrealization of conjoined twins. In R. G. Thomson (Ed.), Freakery: Cultural spectacles of the extraordinary body (pp. 338-355). New York University Press.

Clissold, B. D. (2004). Candid Camera and the origins of reality TV: Contextualising a historical precedent. In S. Holmes \& D. Jermyn (Eds.), Understanding reality television (pp. 33-53). Routledge.

Cooke-Jackson, A. F., \& Hansen, E. K. (2008). Appalachian culture and reality TV: The ethical dilemma of stereotyping others. Journal of Mass Media Ethics, 23(3), 183-200.

Dennett, A. S. (1996). The dime museum of freak show reconfigured as talk show. In R. G. Thomson (Ed.), Freakery: Cultural spectacles of the extraordinary body (pp. 315-326). New York University Press.

Feeley, S., Berger, J., Valastro, B., \& Edwards, A. (Produc- 
ers). (2009-present). Cake boss [Reality Television]. Highnoon Entertainment and Cakehouse Media.

Franzino, J. (2015). Freak show aesthetics: Exceptional bodies and racial citizenship in nineteenth-century America. [Unpublished doctoral thesis]. University of Virginia.

Hawkins, J. (1996). "One of us": Tod Browning's Freaks. In R. G. Thomson (Ed.), Freakery: Cultural spectacles of the extraordinary body (pp. 265-276). New York University Press.

Hill, A. (2005). Reality TV: Performance, authenticity, and television audiences. In J. Wasko (Ed.), A Companion to television (pp. 449-467). Blackwell Publishing.

Hill, A. (2007). Restyling factual TV-Audiences, news, documentary and reality genres. Routledge.

History Channel. (2021). Swamp people-About. https:// www.history.com/shows/swamp-people

Holmes, S., \& Jermyn, D. (2004). Introduction. In Holmes, S. \& Jermyn, D. (Eds.), Understanding reality television (pp. 1-32). Routledge.

Jones, W. (2018). Redefining the reel: How Skam redefines traditional notion of reality and fictional television. [Unpublished Master's dissertation]. University of KwaZulu-Natal.

Knox, D. (2016, March 22). Tim Dormer spills on Big Brother manipulation. TV Tonight. https://tvtonight. com.au/2016/03/tim-dormer-spills-on-big-brothermanipulation.html

MSN Entertainment. (2016). Watch Outdaughtered: Life With Quints Season 1 Episode 5. https://www. msn.com/en-us/entertainment/rf-watch-online/tvshows/outdaughtered-a-quint-s-life/season-1/ episode-5

Nicholas, J., \& Chambers, L. (2016). In search of mon- key girl: Disability, child welfare, and the freak show in Ontario in the 1970s. Journal of Canadian Studies, 50(3), 639-668.

O'Donnell, V. (2017). Television criticism (3rd ed.). SAGE.

Oulette, L., \& Murray, S. (2004). Introduction. In S. Murray \& L. Oulette (Eds.), Reality TV-Remaking television culture (pp. 1-18). New York University Press.

Rennels, T. R. (2015). You better redneckognize: White working-class people and reality television. [Unpublished doctoral thesis]. University of South Florida.

Rothfels, N. (1996). Aztecs, Aborigines, and Ape-People: Science and freaks in Germany, 1850-1900. In R. G. Thomson (Ed.), Freakery: Cultural spectacles of the extraordinary body (pp. 158-172). New York University Press.

Sardar, Z. (2000, November 6). The rise of the voyeur. The New Statesman. https://www.newstatesman.com/ node/152309

Stephens, R. L. (2004). Socially soothing stories? Gender, race and class in TLC's A Wedding Story and A Baby Story. In S. Holms \& D. Jermyn (Eds.), Understanding reality television (pp. 191-210). Routledge.

Swift, N. (2015, September 25). The rise and fall of the Duggar family. Nicki Swift. https://www.nickiswift. com/3271/rise-fall-duggar-family

Thompson, A., Stringfellow, L., Maclean, M., MacLaren, A., \& O'Gorman, K. (2015). Puppets of necessity? Celebritisation in structured reality television. Journal of Marketing Management, 31(5/6), 478-501.

Thomson, R. G. (1996). Introduction: From wonder to error-A genealogy of freak discourse in modernity. In R. G. Thomson (Ed.), Freakery: Cultural spectacles of the extraordinary body (pp. 1-22). New York University Press.

\section{About the Author}

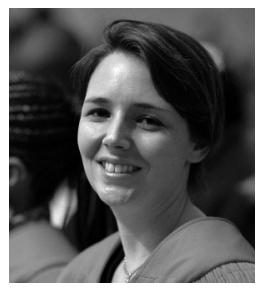

Sandra Pitcher (PhD) is a Senior Lecturer in Media and Cultural Studies, and Academic Leader for the Creative Arts at the University of KwaZulu-Natal (Pietermaritzburg Campus). She is a dedicated Teacher and teaches modules in Media Studies, Cultural Studies, Corporate Communication, Journalism, Television Studies and, when the need arises, Film Studies. She is also a passionate Researcher whose primary research interests rest in new media, television studies, journalism, and media ethics (with a special focus on the concept of "Ubuntu”). 